\title{
Ecological diversity and conservation of wild edible fruit trees species in the Lama Forest Reserve in Benin
}

Symphorien Ag BAHOUng BA ${ }^{1,3}$ Achille Ephrem AsSOG BADJO ${ }^{1}$ Flora Josiane CHADARE ${ }^{2}$ Rodrigue IDOHOU ${ }^{4}$ Valère KolaWOLÉ SALAKO 4 Eric EtChIKINTO AgOYI ${ }^{1,3}$ Romain Lucas GLÈLÈ KAKAï ${ }^{4}$

${ }^{1}$ University of Abomey-Calavi Faculty of Agronomic Sciences Laboratory of Applied Ecology 01 PO Box 526, Cotonou Benin

${ }^{2}$ University of Agriculture of Kétou School of Sciences and Techniques for Preservation and Processing of Agricultural products BP 114, Sakété

Republic of Benin

${ }^{3}$ Makerere University PO Box 7062, Kampala Uganda

${ }^{4}$ University of Abomey-Calavi Faculty of Agronomic Sciences Laboratory of Biomathematics and Forest Estimations 04 PO Box 1525, Cotonou Benin

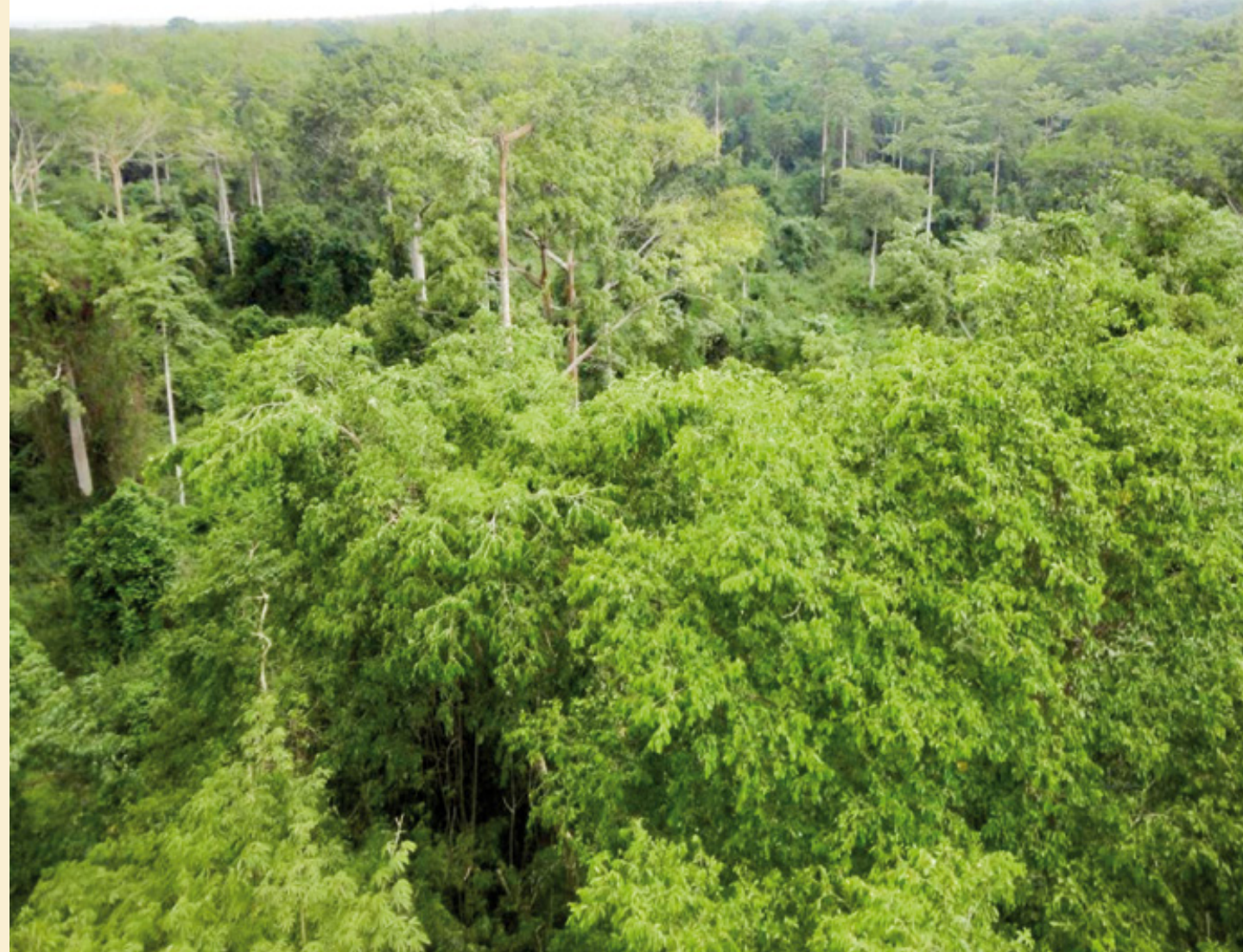

Photo 1.

Aerial view of the Lama Forest Reserve in Benin. Photo S. Agbahoungba. 


\section{RÉSUMÉ}

\section{DIVERSITÉ ÉCOLOGIQUE ET CONSERVATION D'ARBRES SAUVAGES À FRUITS COMESTIBLES DANS LA RÉSERVE FORESTIĖRE DE LAMA AU BÉNIN}

Une bonne connaissance des interactions entre les forêts et les communautés humaines voisines est indispensable à la gestion participative des ressources forestières. La présente étude s'est attaché à déterminer la diversité écologique des arbres sauvages à fruits comestibles (ASFC) dans la Réserve forestière de Lama, zone protégée dans le sud du Bénin, et à définir des stratégies de conservation adaptées. Un inventaire des ASFC a été réalisé sur 53 placettes systématiquement délimitées dans des forêts denses typiques, de forêt dense dégradée et de jachère dans la Réserve forestière de Lama, ainsi qu'une enquête ethnobotanique auprès de 136 participants. Les habitats des ASFC ont été identifiés à partir d'une Analyse des Correspondances Simples sur les données de densité. Une liste d'especes prioritaires a été générée par la méthode des rangs composés : Dialium guineense, Diospyros mespiliformis, Drypetes floribunda, Mimusops andogensis et Pterocarpus santalinoides en forêt dense typique ; Pancovia bijuga, Psidium guajava et Lecaniodiscus cupanioides en forêt dense dégradée ; Ficus capensis et Spondias mombin dans les jachères. Contrairement aux autres essences, la densité moyenne de $D$. guineense, $D$. mespiliformis, D. floribunda, L. cupanioides et $M$. andongensis varie de manière significative $(P<0,01)$ selon les types de végétation. Les ASFC recensés sont principalement utilisés dans l'alimentation et la pharmacopée. Les essences à conserver en priorité sont $P$. guajava, S. mombin, $F$. capensis, $P$. santalinoides et $P$. bijuga. Des efforts de protection renforcés sont nécessaires en forêt dense dégradée et dans les zones de jachère pour assurer la conservation de ces essences. D'autre part, il convient d'intégrer les ASFC prioritaires dans des programmes de plantation afin de réduire la pression des communautés humaines voisines.

Mots-clés : conservation, réserve forestière de Lama, diversité, arbres sauvages à fruits comestibles.

\section{ABSTRACT}

\section{ECOLOGICAL DIVERSITY AND CONSERVATION OF WILD EDIBLE FRUIT TREE SPECIES IN THE LAMA FOREST RESERVE IN BENIN}

Understanding interactions between forests and neighbouring human communities is crucial to participative management of forest resources. This study aimed to determine the ecological diversity of wild edible fruit tree (WEFT) species in the Lama Forest Reserve, a protected area in southern Benin, and strategies for their conservation. An inventory of WEFT species was carried out in 53 systematically delimited plots in typical dense forest, degraded dense forest and young and old fallows in the Lama Forest Reserve. An ethnobotanical survey was conducted with 136 respondents and the WEFT species habitats were identified by applying a Simple Correspondence Analysis to the density data. A list of priority species was generated using the Compound Ranking System method. The results revealed ten WEFT species, including Dialium guineense, Diospyros mespiliformis, Drypetes floribunda, Mimusops andogensis and Pterocarpus santalinoides in typical dense forest; Pancovia bijuga, Psidium guajava and Lecaniodiscus cupanioides in degraded dense forest; and Ficus capensis and Spondias mombin in fallows. Unlike the other species, the average density of $D$. guineense, $D$. mespiliformis, $D$. floribunda, L. cupanioides and M. andongensis varied significantly $(P<0.01)$ from one vegetation type to another. The WEFT species recorded were mainly used for food and medicinal purposes. Top priority species for conservation were $P$. guajava, S. mombin, F. capensis, P. santalinoides and $P$. bijuga. More protection efforts should target the degraded dense forest and fallow areas to ensure the conservation of these species. Further, priority WEFT species need to be included in plantation programmes to reduce pressure from riparian populations.

Keywords: conservation, Lama forest reserve, diversity, wild edible fruit tree.

\section{DIVERSIDAD ECOLÓGICA Y CONSERVACIÓN DE FRUTALES SILVESTRES COMESTIBLES EN LA RESERVA FORESTAL DE LAMA EN BENÍN}

El manejo participativo de los recursos forestales requiere un buen conocimiento de las interacciones entre bosques y poblaciones aledañas. El objetivo de este estudio es determinar la diversidad ecológica de los árboles frutales silvestres comestibles (AFSC) y definir las estrategias de conservación adaptadas en la Reserva Forestal de Lama, un área protegida del sur de Benín. Se llevó a cabo un inventario de especies de AFSC en 53 parcelas sistemáticamente delimitadas en zonas típicas de bosque denso, bosque denso degradado y barbecho de la reserva Forestal de Lama. Se realizó una encuesta etnobotánica con 136 participantes y se identificaron los hábitats de AFSC mediante análisis de correspondencias simples de los datos de densidades. El método de rango de los componentes permitió generar una lista de diez especies prioritarias: Dialium guineense, Diospyros mespiliformis, Drypetes floribunda, Mimusops andogensis y Pterocarpus santalinoides en bosque denso típico; Pancovia bijuga, Psidium guajava y Lecaniodiscus cupanioides en bosque denso degradado; y Ficus capensis y Spondias mombin en barbechos. A diferencia de las otras especies, la densidad promedio de $D$. guineense, $D$. mespiliformis, $D$. floribunda, L. cupanioides y $M$. andongensis varía de modo significativo $(P<0.01)$ según el tipo de vegetación. La mayoría de AFSC inventariados tiene un uso alimentario y medicinal. Las especies prioritarias para su conservación son: P. guajava, S. mombin, F. capensis, $P$. santalinoides y $P$. bijuga. Es necesario reforzar los esfuerzos de protección en el bosque denso degradado y las zonas de barbecho para garantizar la conservación de estas especies. Por otra parte, deben incluirse los AFSC prioritarios en los programas de siembra para reducir la presión de las poblaciones aledañas.

Palabras clave: conservación, reserva forestal de Lama, diversidad, árboles frutales silvestres comestibles. 


\section{Introduction}

Non timber forest products (NTFPs) are the products extracted from forest ecosystems and which are used for food, animal feed, medicine, and income generation or endowed of a social, cultural or religious signification. These resources constitute an important income source for local populations. In rural areas in Sub-Saharan Africa, NTFPs contribute up to $46 \%$ of population's income (Mahapatra et al., 2005; Assogbadjo et al., 2009; Fandohan et al., 2010).They include wild edible fruit tree (WEFT) species which are treasured for their fruits, seeds, leaves, barks, and roots (Belinda et al., 2013). These non-cultivated foods are used as diet supplement, as coping mechanism in food shortage times, and provide an important safety net for the rural households (Takasaki et al., 2004) while contributing to their food and nutritional security. Indeed, WEFT species are one of the best sources of vitamin A, iron, calcium, copper, magnesium, phosphorus, zinc, antioxidants and other nutritive element useful for a balanced nutrition (Mahapatra et al., 2012). As such they could help to substantially reduce food insecurity in rural communities especially during food shortage periods.

The high nutritional value, the easy access, the lack of cares and the good organoleptic quality of WEFT species have led to their overexploitation even in natural forests which constitute the reservoir of WEFT species (Rigg et al., 2009). Within the same context, FAO (2010) reported that African forests' coverage decreases at an alarming rate due to human pressure. This forest degradation has been pointed out as one of the major reason of the progressive disappearance of WEFT species in developing countries (Krusters et al., 2006). For instance, Benin has lost nearly one third of its forest coverage since 1990, with the highest lost rate (2.4\% per year) between 2000 and 2005 (FAO, 2012). Its protected areas represent one of the last refuges of WEFT species, while some could be found on farms (Hermans et al., 2004). Although, protected areas are subject to limited human activities, species within these areas are sometimes illegally exploited (Racquel, 2014).

Lama Forest Reserve located in the southern part of Benin, is one of the last vestiges of natural dense forest within the country. It is a mosaic of forests and fallows (young fallow, old fallow, typical dense forest and degraded dense forest) with different ecological patterns (types of soil and diversity of species) (Bonou et al., 2009). The young fallow is characterized by the predominance of Chromolena odorata L. (75\% of cover of the vegetation), whereas the old fallow is characterized by the predominance of Ceiba pentandra L., Ficus capensis Thunb. and Anogeissus leiocarpa (DC.) Guill. The typical dense forest is dominated by Afzelia africana Sm., Ceiba pentandra L., Dialium guineense Willd., Diospyros mespiliformis Hochst. and Mimusops andongensis Bruce. The degraded dense forest is dominated by
Cynometra megalophylla Harms (Bonou et al., 2009). These vegetation types are protected since they are included in the reserve, but more effort are concentrated on the degraded dense forest and the fallows to recover the equilibrium with the typical dense forest. Due to this diverse patterns, it is expected that distribution and density of plant species differ from one vegetation type to another. The management practice within this forest consists on a yearly planting of tree species around the central core of the reserve. These species often included are: Tectona grandis L., Gmelina arborea Roxb., and Khaya senegalensis (Desr.) A. Juss. (Djego et al., 2007). However, no edible fruit trees plantations have been envisaged which may contribute to the reduction of human pressure on WEFT species in the reserve. Because all species cannot be conserved at once and do not receive the same pressure and threats, it is necessary to inventory the diversity of WEFT species in the Lama Forest Reserve and establish priorities for conservation. This could help to have a list of species deserving conservation actions within the natural forest and bring out those to target in management action. This is crucial as limited funds are often available for species conservation (Brehm et al., 2010; IUCN, 2011).

Ethnobotanical, food, cultural, economic and pharmacological aspects of WEFT species have been widely documented in Africa (Kebu and Fassil, 2006; Racquel, 2014) and more specifically in Benin (Assogbadjo, 2000; Codjia et al., 2003; Chadare et al., 2008; Fandohan et al., 2010). Most of these studies focused on species in agroforestry systems. Few studies had targeted natural populations of WEFT species within protected areas. Such information is however critical as it can help to design a sustainable management strategies for these species even in protected areas. An active conservation of WEFT species diversity, requires the establishment of priority within species (Maxted et al., 2006). But there is no single method to develop effective strategies for biodiversity conservation. In the approach described by Brehm et al. (2010), eight criteria are commonly used and four methods are generally applied to these criteria to select the priorities species. Taking into account that Lama Forest Reserve is a protected area, four criteria were able to discriminate the WEFT species identified. These criteria included: distribution (within the forest reserve), ethnobotanical value, native status and threat assessment. Compound Ranking System method was used in this study to identify the priority species as it was the most suitable among all four methods developed by Brehm et al. (2010). Compound Ranking System method is easy to verify, flexible and easy to apply for a large data set (Idohou et al., 2013).

This study aimed at assessing the ecological diversity of WEFT species and generate a list of priority species for further reforestation purpose in the Lama Forest Reserve in Benin. 


\section{Material and methods}

\section{Study area}

The Lama Forest Reserve is located between 6 ${ }^{\circ} 55^{\prime}$ and $7^{\circ} 00^{\prime}$ latitude North and $2^{\circ} 4^{\prime}$ and $2^{\circ} 12^{\prime}$ longitude East in Southern Benin (White, 1983; figure 1). The forest was gazetted by law in 1946 as forest reserve (Bonou et al., 2009). Lama Forest Reserve covers 4,777 ha of which 1,900 ha of dense forest, and the remaining being fallows (young and old fallows) (Bonou et al., 2009, photo 1). The surrounding area of the reserve is occupied by the plantations of $T$. grandis and G. arborea (292 ha). The annual average rainfall fluctuates between $1,000 \mathrm{~mm}$ and 1,200 $\mathrm{mm}$ and the relative humidity averages $74.5 \%$. Lama Forest Reserve is in a depression of an average altitude of $60 \mathrm{~m}$. The soil is clayey, more than 2 meters in depth (Akpona et al., 2008).

The local populations around the Lama Forest Reserve belong mainly to Fon, Holli and at a lesser extent to Adja sociolinguistic groups. Primarly, they settled inside the forest, but later in 1984, they have been settled outside the forest for the purpose of forest management plan. The main activities around the forest are agriculture, animal rearing, hunting and small-scale trading.

\section{Sampling and data collection}

A systematic sampling method was used following the seven transect lines of the Lama Forest Reserve. This method enabled to achieve a good precision by distributing the plots in all the vegetation communities (Rondeux, 1999). Square plots of $45 \mathrm{~m} \times 45 \mathrm{~m}$ (Salako et al., 2013) were systematically demarcated at each kilometer with first plots installed at 15-20 meters away from each path. In total, 53 plots (figure 1) were installed in the four vegetation types of the forest reserve: 13 plots in the typical dense forest; 14 in the degraded dense forest; 14 in the young fallow; 8 in old fallow and 4 in the surrounding plantations. The 4 plots demarcated in the surrounding plantations were not considered in the analysis because of the absence of WEFT species in these plots. Within each plot, the diameter at breast height ( $\mathrm{dbh}$ ) of individual with $\mathrm{dbh} \geq 5 \mathrm{~cm}$ was measured for all WEFT species and non-WEFT species.

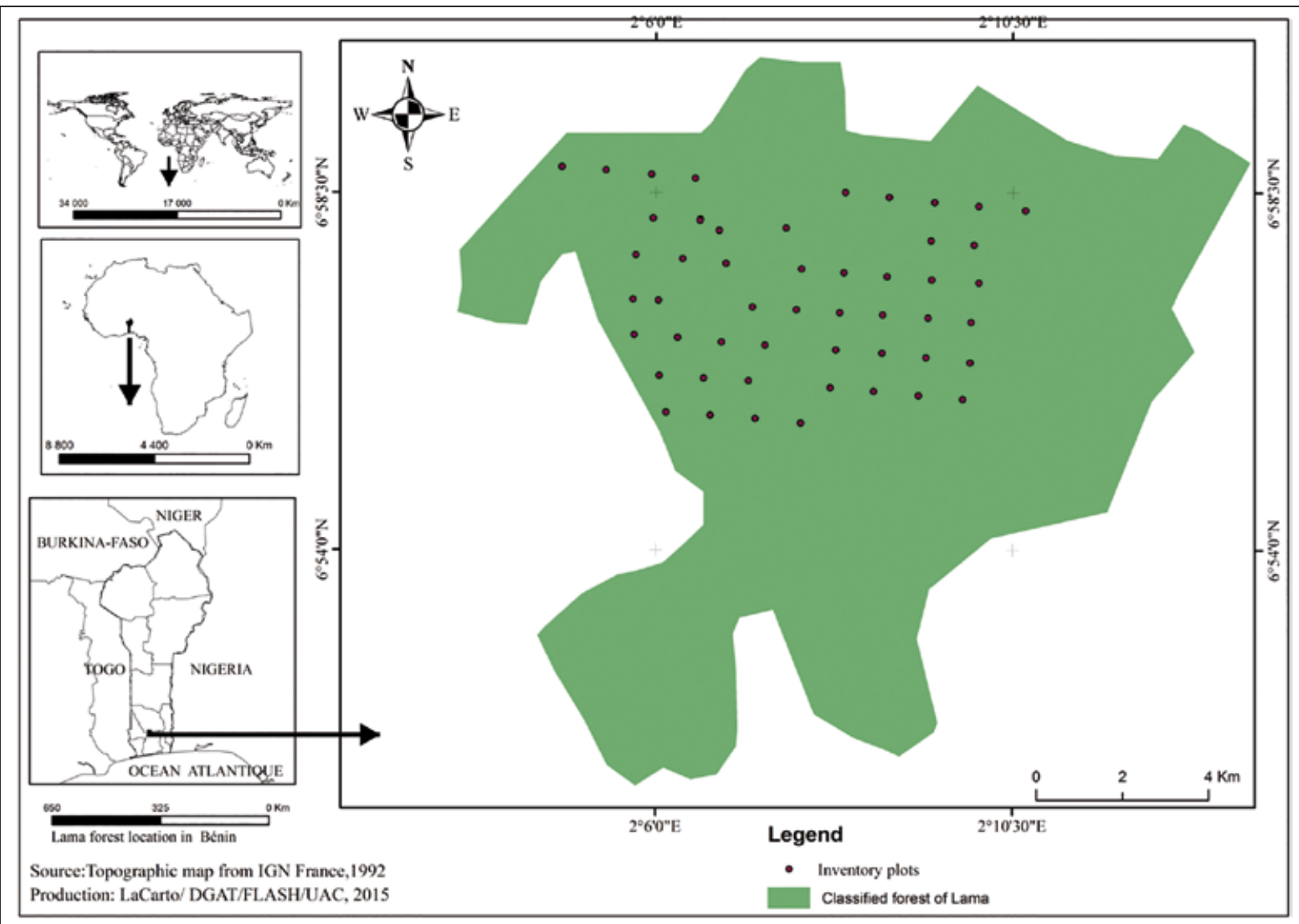

Figure 1.

Map showing the location of the Lama Forest Reserve in Benin and the plots.

Plots are square plots of $45 \mathrm{~m} \times 45 \mathrm{~m}$ systematically demarcated at each kilometer following the seven transect lines of the Lama Forest Reserve. 


\section{Data analysis}

Assessment of the ecological diversity and structure of wild edible fruit tree species in the Lama Forest Reserve

The exhaustive list of WEFT species within each inventory plot was established in each plot by recording the name of each species and the total number of its individuals. A contingency table describing the number of each edible fruit tree according to each vegetation type was then drawn. This matrix was submitted to a Simple Correspondence Analysis (CA) using R 3.0.2 (Ihaka and Gentlman, 1996) to determine the preferred habitat of each WEFT species.

The tree density and Green index were calculated to analyze the structure of the WEFT species. Tree density ( $D$, in trees/ha) is the average number of trees per hectare.

Means of $D_{i j}$ values were calculated for each vegetation types and for each species. An analysis of variance was performed on density values to test whether there is any significant difference (at $5 \%$ significance level) between vegetation types with respect to each WEFT species. When the differences were significant a Student Newman and Keuls (SNK) test was applied to separate the means.

Green index (GI) was calculated to detect the spatial configuration of each WEFT species by considering all individuals with a diameter at breast height $(\mathrm{dbh}) \geq 5 \mathrm{~cm}$ of in each vegetation type, using the formula (Green, 1966):

$G I=\frac{\frac{S^{2}}{n-1}-1}{(1)}$

In equation $1, \mathrm{~m}$ is the average density of a given WEFT species; $\mathrm{S}^{2}$ is the variance of the densities in the different vegetation types and $n$ is the total number of trees counted for this species in a given vegetation type.

Values of Green index vary from 0 (random distribution) to 1 (aggregative distribution). But this index could display values that were superior to 1 in the case of large variability in density values within the plots in the various vegetation types or when the environment is disturbed (Green, 1966).

The diameter size (diameter at breast height $\geq 5 \mathrm{~cm}$ ) class distribution (SCD) of each WEFT species was also established. The 3-parameters of theoretical distribution of Weibull were then adjusted to the observed distributions (Johnson, 1970). Its probability density function for a random variable $\mathrm{x}$ is:

$f(x)=\frac{c}{b}\left(\frac{x-a}{b}\right)^{c-1} \exp \left[-\left(\frac{x-a}{b}\right)^{c}\right]_{(2)}$

In equation 2, "a" is the location parameter $(\mathrm{a}=5 \mathrm{~cm}$, which is the minimum value of dbh observed in the study area), "b" the scale parameter, "c" the shape parameter, and exp [ ] is the exponential function (the base of the natural logarithm). The random variable $x$ is the stem diameter at breast height and is assumed to be a continuous random variable.

\section{Identification of the most important WEFT species for riparian populations of Lama Forest Reserve}

The use value index (UV) was used to identify the most important WEFT species. This index was estimated as the sum of the number of uses mentioned by each informant for each WEFT species divided by the total number of informants. For a WEFT species $k$, the use value $U_{\mathrm{k}}$ was calculated using the formula (Phillips and Gentry, 1993):

$\mathrm{UV}_{\mathrm{K}}=\frac{1}{\mathrm{n}} \sum_{\mathrm{i}=1}^{\mathrm{n}} \mathrm{n}_{\mathrm{ik}}$

In equation $3, \mathrm{n}$ is the total number of respondents [ $\mathrm{n}=136$ determined using the formula of Dagnelie (1998)], $n_{\mathrm{ik}}$ is the number of different uses mentioned by the informant $i$ for the WEFT species $\mathrm{k}$.

The formula of Dagnelie (1998) is presented as follow:

$n=\frac{U_{(1-\alpha / 2)}^{2} * p(1-p)}{d^{2}}$

In equation $4, \mathrm{n}$ is the total number of respondents, $U_{1-\alpha / 2}$ is the value of the normal random variable for a probability value of $\alpha=0.05 ; U_{1-\alpha / 2} \approx 1.96, p$ is the proportion of respondents using WEFT species $(p \approx 0.68)$, and $d$ is the expected error margin of any parameter to be computed from the survey, which was fixed at 0.08 . Under these assumptions, the sample size used, was $n=136$ respondents.

Multipurpose species (high UV) were given priority compared to less used species (with low UV).

\section{Identification of the priorities Wild edible fruit tree species for conservation within the Lama Forest Reserve}

Compound Ranking System method was used to identify the priority species. The method uses individual criteria to rank the species from the most priority to the least priority. The ranks obtained for each species (according to each of the criterion) was then summed to obtain the total rank from which the priority species were identified. Criteria used included: ethnobotanical value (according to riparian population), native status, distribution (within the forest reserve), and level of threat. The formula and technique used to estimate each of these criteria for the WEFT species are described below:

- Distribution

The distribution of the WEFT species was assessed using the ecological Importance Value Index (IVI). The ecological Importance Value Index (IVI) of a WEFT species i was computed as follows:

$\mathrm{IVI}_{\mathrm{K}}=\mathrm{RD}_{\mathrm{i}}+\mathrm{RF}_{\mathrm{i}}+\mathrm{RDo}_{\mathrm{i}}(5)$

In equation (5) (Assogbadjo et al., 2009):

$R D_{i}$ is the relative density of the species $i ; R F_{i}$ is the relative frequency of the species $i ; R D o_{i}$ is the relative dominance of the species i;

$\mathrm{Do}_{\mathrm{i}}=\frac{\mathrm{a}_{\mathrm{i}} \times \mathrm{N}_{\mathrm{i}}}{\mathrm{n}_{\mathrm{i}}}$

$\mathrm{Do}_{i}$ is the dominance of the species $\mathrm{i}$; ai is the basal area of the species $i ; N_{i}$ is the tree-density of the species $i$ and $n_{i}$ is the total number of individuals encountered for that species. 


\section{Results}

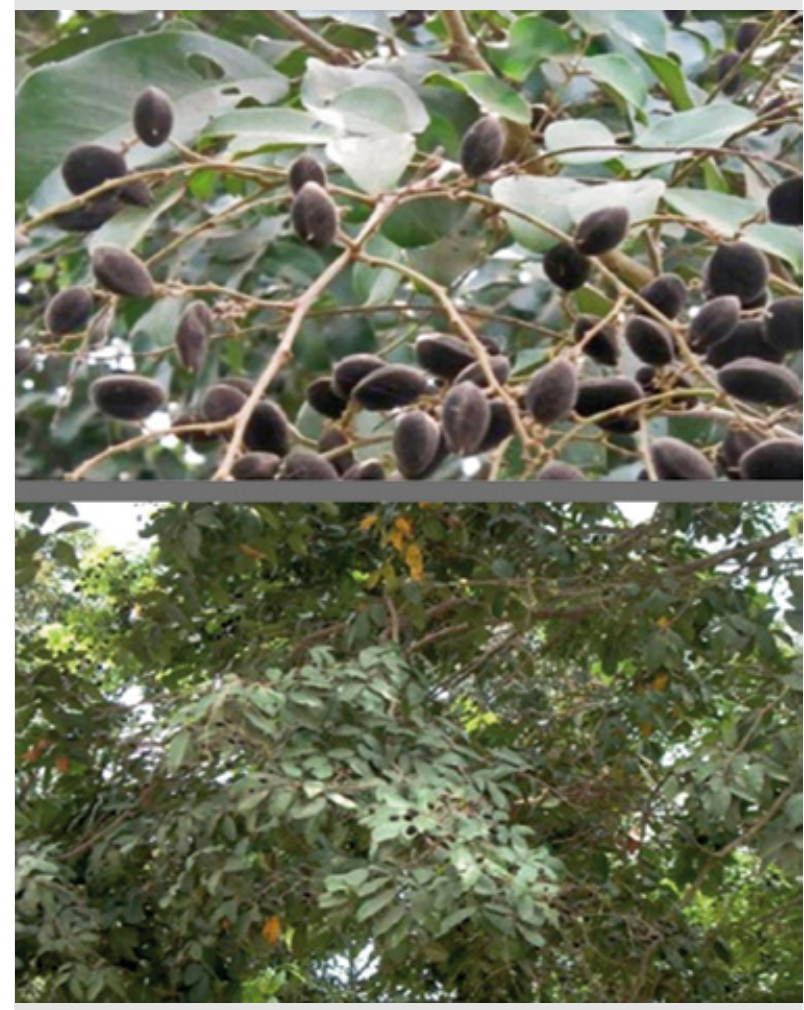

Photo 2.

Fruit and tree of Dialium guineense collected in the Lama Forest Reserve.

Photo S. Agbahoungba.

Values of IVI range from 0 to 3 . The species which had the lowest IVI was priority for conservation.

- Threats assessment

The threat status is the most used criterion to determine conservation priority. Most threatened species received the greatest attention. The red list of IUCN (www.iucnredlist.org) and Benin red list were used to assess the threat of the WEFT species. The different categories used were: Endangered (EN), Vulnerable (VU), Near Threatened (NT), Least Concern (LC), and Data Deficient (DD). The status of each WEFT species was known by using the red list of IUCN and red list of Benin. When the status of a WEFT species was not found in the red list of Benin, we checked it in the red list of the IUCN. Endangered species received greater attention than those that are not under threat.

- Native status

Since the inventory has both native and introduced species, priorities were given to native species.

- Ethnobotanical value

The natural forest of the Lama Forest Reserve is a protected area managed essentially for scientific researches, but the local population harvest fruit from it either in complicity with the security agents or clandestinely.

The ethnobotanical value of the species refers to the importance of the WEFT species for the riparian population. Here we consider the use value as previously developed in equation 3.

\section{Diversity and ecology of WEFT species in the Lama Forest Reserve}

A total of 10 WEFT species belonging to 10 genera and 8 botanical families were encountered in the four vegetation types. These include: Dialium guineense Willd. (photo 2), Diospyros mespiliformis Hochst., Drypetes floribunda Hutch., Mimusops andongensis Bruce, Pterocarpus santalinoides L'Her. ex De., Pancovia bijuga Willd., Psidium guajava L. (photo 3), Lecaniodiscus cupanioides Planch., Ficus capensis Thumb. and Spondias mombin L. (photo 4). The Correspondence Analysis revealed that the two first axes captured $84.6 \%$ of the information contained in the contingency table describing the relationship between WEFT species and the four vegetation types. Correlations between the two axes and the WEFT species indicated that all species except $F$. capensis had better correlation ( $r>0.50$ ) with the first axis which was more correlated to the second axis $(r=0.68)$. Correlations between the axis and the different vegetation types, indicated that typical dense forest and degraded dense forest had better correlation $(r=0.99$ and $r=0.52$ respectively) with the first axis whereas the old fallow and the young fallow were more correlated with the second axis ( $r=0.50$ and $r=0.69$ respectively).

Projection of the WEFT species and the vegetation types in the same axis system defined by the two first axes (figure 2) showed on axis 1, an opposition between typical dense forests which was associated with $D$. guineense, $D$. mespiliformis, $D$. floribunda, $M$. andogensis and $P$. santalinoides; and degraded dense forest associated with $P$. bijuga, $P$. guajava and $L$. cupanioides. On axis 2 , it was also observed an opposition between fallows which were associated with S. mombin and degraded dense forest associated with F. capensis.

\section{Structural characteristics of the wild edible fruit tree species in the Lama Forest Reserve}

The analysis of variance revealed significant difference in tree densities between the different vegetation types $(\mathrm{P}<0.01)$ in $D$. guineense, $D$. mespiliformis, $D$. floribunda, $L$. cupanioides, and M. andogensis but not in F. capensis, P. bijuga, P. guajava, P. santalinoides, and $S$. mombin ( $P$ > 0.05) (table I). As it could be expected, trend in species density was also in accordance with results of the Simple Correspondence Analysis (see previous paragraph). Indeed, a link was observed between species with low density and their distribution around axis 2. Actually, the distribution of $S$. mombin, P. guajava and F. capensis, on the periphery of the graph (figure 2) is mostly explained by the low number of individuals in these species (i.e. their tree density), in each vegetation type.

In order to depict the spatial pattern of each of the WEFT species, Green index was calculated. Values of this index for each WEFT species in each of the different vegetation types showed that a majority of the WEFT species roughly presented a relatively random distribution in the 


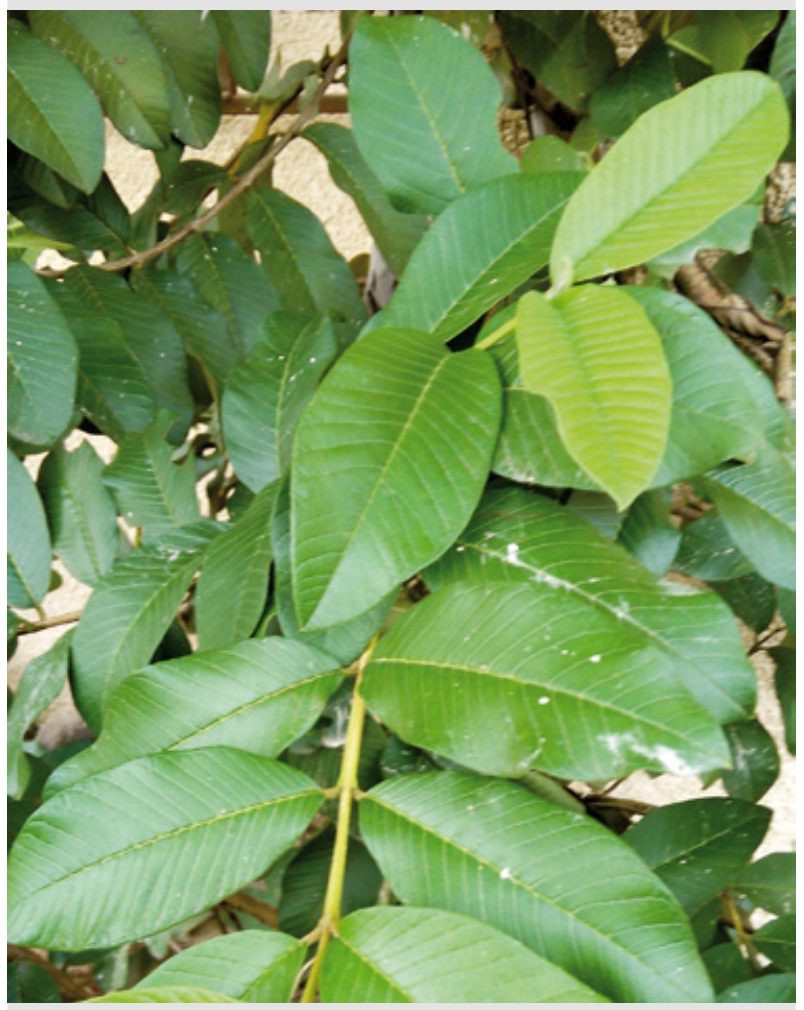

Photo 3.

Tree of Psidium guajava collected in the Lama Forest Reserve. Photo S. Agbahoungba.

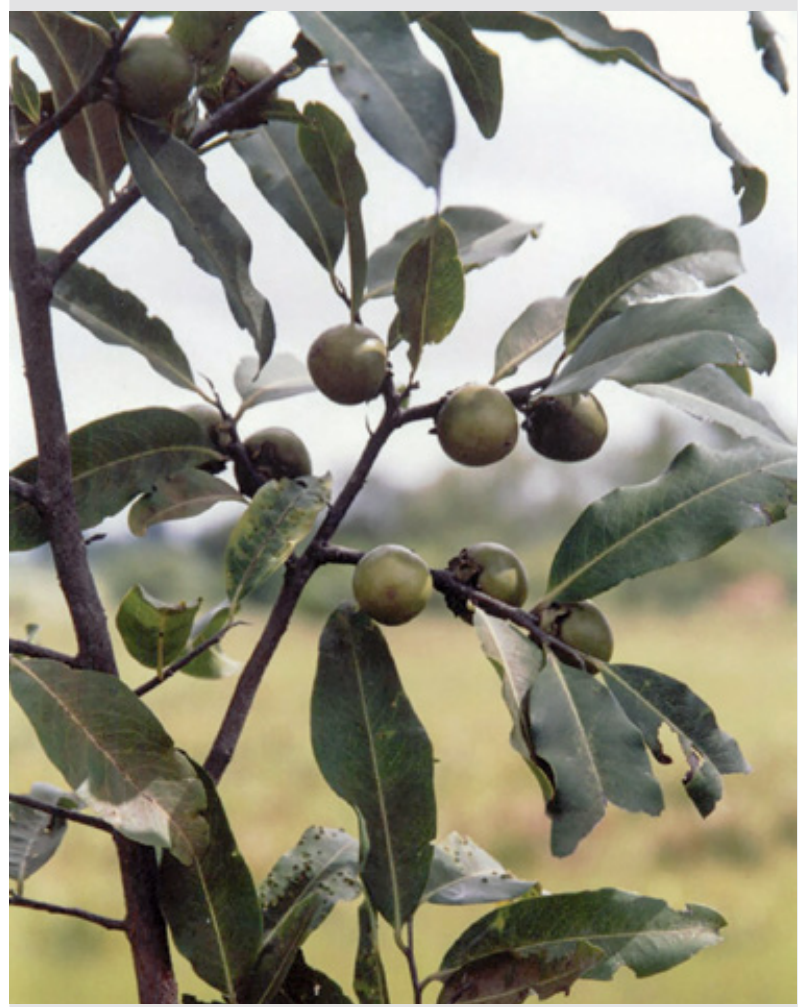

Photo 4.

Tree of Diospyros mespiliformis collected in the Lama Forest reserve. Photo S. Agbahoungba. four vegetation types. However some species including $D$. guineense, $M$. andongensis, and P. bijuga presented in the young fallow, a value of Green index greater than 1 (table II). The same observation was made in the degraded dense forest for L. cupanioides and P. guajava and in old fallow for L. cupanioides and P. bijuga. An aggregative distribution was observed for $F$. capensis in the young fallow and for S. mombin in the typical dense forest (table II).

Distribution in stem diameter classes for each of the WEFT species (figure 3) showed a right skewed ("inverted J") distribution, characteristic of multispecific forest stands or an uneven-aged structure with the predominance of young individuals or trees with small diameter. The individuals of WEFT species with a stem diameter between 6 and $15 \mathrm{~cm}$ were the most represented per hectare, except $M$. andogensis for which most individuals diameter was around $32 \mathrm{~cm}$. The highest difference between these structures were observed on the scale parameter which fluctuated between $4.4 \mathrm{~cm}$ (P. guajava) and $20.6 \mathrm{~cm}$ (M. andongensis). The stem diameter classes of $12 \mathrm{~cm}$ and $30 \mathrm{~cm}$ were not recorded in $P$. guajava and $P$. bijuga respectively. The stem diameter class's distribution of $P$. santalinoides was not generated as very few individuals of that species were recorded in the forest.

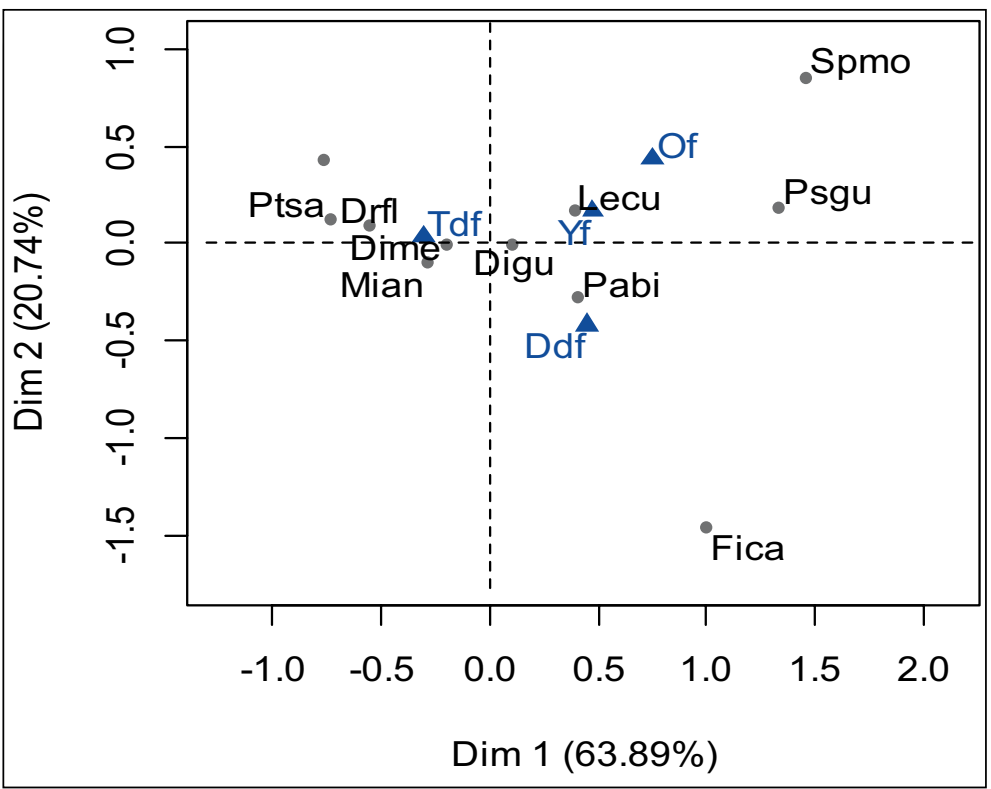

Figure 2.

Projection of the ten WEFT species and the vegetation types on the two axes of the Simple Correspondence Analysis (CA). Species (in black dots): Fica = Ficus capensis;

Pabi = Pancovia bijuga; Mian = Mimusosps andongensis; Spmo = Spondias mombin; Psgu = Psidium guajava; Lecu = Lecaniodiscus cupanoides; Ptsa = Pterocarpus santalinoides; Drfl = Drypetes floribunda; Digu $=$ Dialium guineense , Dime $=$ Dyospyros mespiliformis .

Vegetation types (in blue triangles): $\mathrm{Tdf}=$ Typical dense forest; $\mathrm{Ddf}=$ Degraded dense forest; $\mathrm{Yf}=$ Young fallow; Of $=$ Old fallow 
Table I.

Tree density of each Wild Edible Fruit Tree (WEFT) species per vegetation type in the Lama Forest Reserve.

\begin{tabular}{l|c|c|c|c|}
\hline WEFT species & \multicolumn{1}{c}{ TDF } & DDF & YF & OF \\
\cline { 2 - 6 } & & & & \\
Dialium guineense & $120.4 \mathrm{a} \pm 4.39$ & $44.1 \mathrm{~b} \pm 3.99$ & $17.6 \mathrm{c} \pm 7.46$ & $48.2 \mathrm{~b} \pm 4.33$ \\
\hline Diospyros mespiliformis & $83.0 \mathrm{a} \pm 5.79$ & $15.6 \mathrm{~b} \pm 2.50$ & $4.6 \mathrm{c} \pm 2.24$ & $11.7 \mathrm{~b} \pm 3.73$ \\
\hline Drypetes floribunda & $64.2 \mathrm{a} \pm 4.15$ & $2.9 \mathrm{~b} \pm 1.86$ & $3.2 \mathrm{~b} \pm 3.96$ & $0.6 \mathrm{~b} \pm 1.75$ \\
\hline Ficus capensis & $0.4 \mathrm{~b} \pm 1.37$ & $7.8 \mathrm{a} \pm 6.21$ & $0.7 \mathrm{~b} \pm 1.87$ & - \\
\hline Lecaniodiscus cupanioides & $15.2 \mathrm{a} \pm 2.50$ & $7.0 \mathrm{~b} \pm 3.35$ & $2.1 \mathrm{~b} \pm 1.89$ & $12.4 \mathrm{a} \pm 5.34$ \\
\hline Mimusosps andongensis & $28.9 \mathrm{a} \pm 3.51$ & $6.6 \mathrm{~b} \pm 2.31$ & $4.2 \mathrm{~b} \pm 3.61$ & $0.7 \mathrm{c} \pm 1.87$ \\
\hline Pancovia bijuga & $3.8 \mathrm{a} \pm 1.30$ & $1.7 \mathrm{a} \pm 1.14$ & $2.8 \mathrm{a} \pm 3.26$ & - \\
\hline Psidium guajava & $0.4 \mathrm{c} \pm 1.37$ & $4.5 \mathrm{~b} \pm 3.45$ & $1.1 \mathrm{c} \pm 2.29$ & $8.5 \mathrm{a} \pm 4.09$ \\
\hline Pterocarpus santalinoides & $0.4 \pm 1.37$ & - & - & - \\
\hline Spondias mombin & - & $1.7 \mathrm{a} \pm 1.61$ & $1.4 \mathrm{a} \pm 1.27$ & $3.5 \mathrm{a} \pm 2.13$ \\
\hline
\end{tabular}

TDF = Typical Dense Forest; DDF = Degraded Dense Forest; YF = Young Fallow; OF = Old Fallow

Mean \pm standard error of tree density (trees/hectare).

Number of replicates of $D$. guineense in TDF, DDF, YF and OF are 317, 116, 20 and 78 respectively. Number of replicates of D. mespiliformis in TDF, DDF, YF and OF are 202, 41, 13, 19 individuals respectively. Number of replicates of $D$. floribunda in TDF, DDF, YF and OF are $162,7,9,1$ individuals respectively. Number of replicates of $F$. capensis in TDF, DDF, YF and OF are $1,19,2$ and 0 respectively. Number of replicates of $L$. cupanioides are 40,18, 6 and 20. Number of replicates of $M$. andongensis are 80, 16, 8 and 1. Number of replicates of $P$. bijuga are 10, 8, 8 and 0 . Number of replicates of $P$. guajava are 1, 11, 3 and 12 . Number of replicates of $P$. santalinoides are 1, 0, 0 and 0 . Number of replicates of S. mombin are 0, 4, 8 and 12 . In the same row, means with different letters are significantly different $(P<0.05)$ using Student Newman Keuls’ test.

Table II.

Green index of each Wild Edible Fruit Trees (WEFT) species per vegetation type in the Lama Forest Reserve.

\begin{tabular}{|c|c|c|c|c|}
\hline WEFT species & TDF & DDF & YF & OF \\
\hline Dialium guineense & 0.16 & 0.35 & $2.46^{*}$ & 0.38 \\
\hline Diospyros mespiliformis & 0.40 & 0.21 & 0.44 & 0.99 \\
\hline Drypetes floribunda & 0.26 & 0.26 & 0.13 & 0.00 \\
\hline Ficus capensis & 0.00 & 0.05 & $1.00^{\star}$ & 0.00 \\
\hline Lecaniodiscus cupanioides & 0.32 & $1.16^{*}$ & 0.29 & $1.92^{*}$ \\
\hline Mimusosps andongensis & 0.39 & 0.28 & $1.44^{\star}$ & 0.00 \\
\hline Pancovia bijuga & 0.11 & 0.03 & $3.03^{*}$ & $1.60^{\star}$ \\
\hline Psidium guajava & 0.00 & $1.82^{\star}$ & 0.50 & 0.00 \\
\hline Pterocarpus santalinoides & 0.00 & 0.00 & 0.14 & 0.00 \\
\hline Spondias mombin & $1.00^{\star}$ & 0.08 & 0.14 & 0.72 \\
\hline
\end{tabular}




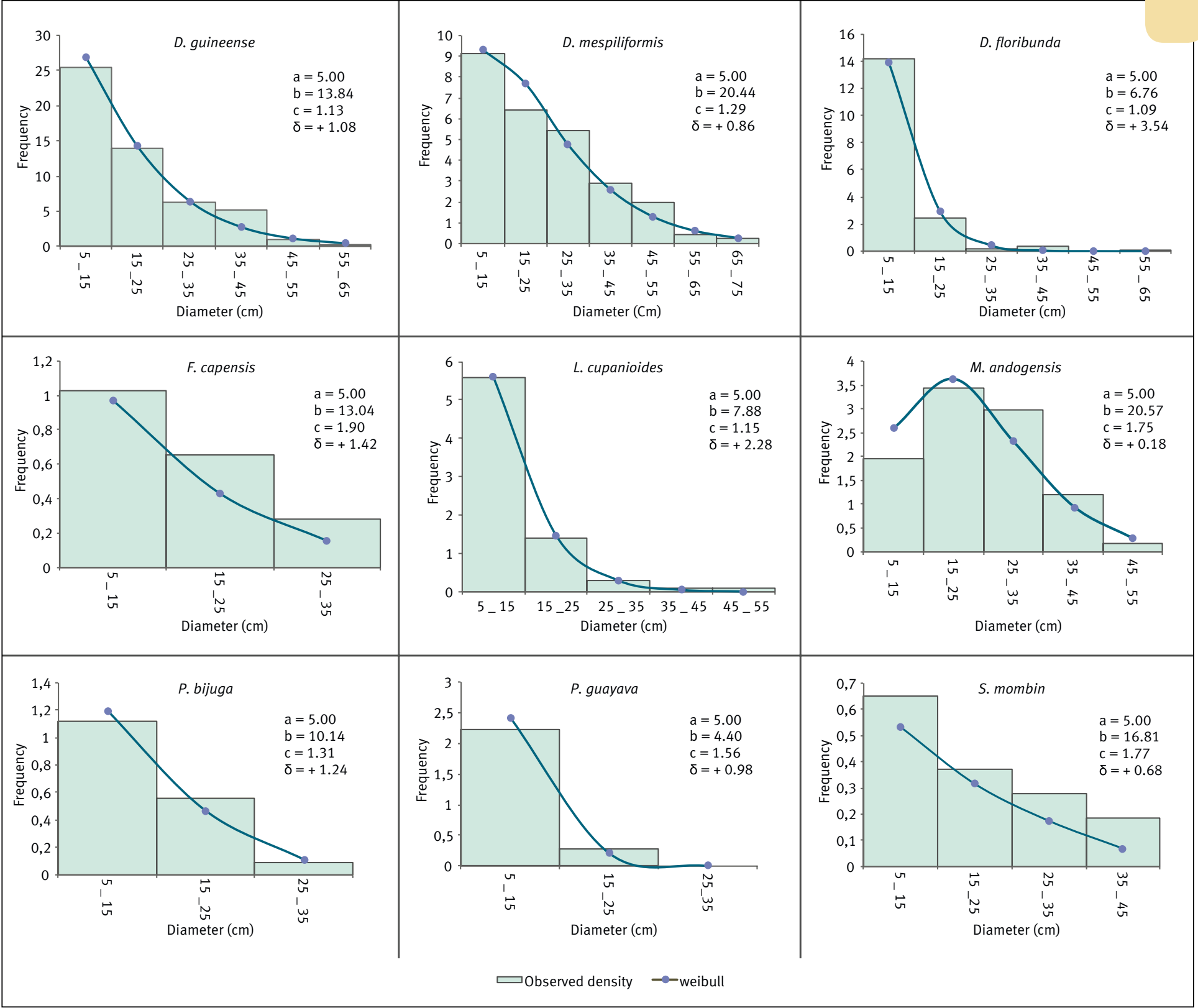

\section{Figure 3.}

Diameter size class distribution (SCD) of each wild edible fruit tree.

$\mathrm{a}=5 \mathrm{~cm}$ and represents the minimum value of the diameter at breast height (dbh) observed in the forest, $\mathrm{b}$ is the scale parameter, $\mathrm{c}$ is the shape parameter and $\delta$ the standard deviation.

Ecological importance value index (IVI) revealed $D$. guineense and $D$. mespiliformis as the top two most ecologically important WEFT species (IVI $=1.424$ and 0.794 respectively) whereas the least important was $P$. santalinoides (IVI = 0.003) (table III).

All WEFTs species recorded in the Lama Forest reserve were conserved in-situ.

The compound ranking system method applied on the uses values of WEFT species revealed that $D$. guineense, P. guajava, S. mombin, D. mespiliformis and D. floribunda were defined as the five top priority species. According to the native status, the five top species were $D$. guineense,
D. mespiliformis, D. floribunda, P. bijuga and L. cupanoides. The compound ranking method applied on the importance value index showed that the top five species were $P$. santalinoides, F. capensis, P. bijuga, S. mombin, D. floribunda. The same method applied on the threat status showed that P. guajava, F. capensis, M. andogensis, P. santalinoides, L. cupanioides were the top priority species (table III).

The rank of each species (summing rank from individual criterion) revealed $P$. guajava, S. mombin, $F$. capensis, $P$. santalinoides, and $P$. bijuga as the top priority WEFT species for conservation in the Lama Forest Reserve (table III). 
Table III.

Results of Compound Ranking System of the Wild Edible Fruit Trees (WEFT) species inventoried in the Lama Forest Reserve.

\begin{tabular}{|c|c|c|c|c|c|c|c|c|c|c|c|c|c|c|}
\hline $\begin{array}{l}\text { WEFT } \\
\text { species }\end{array}$ & UV & Rank & $\begin{array}{l}\text { WEFT } \\
\text { species }\end{array}$ & $\begin{array}{l}\text { Native } \\
\text { status }\end{array}$ & Rank & $\begin{array}{l}\text { WEFT } \\
\text { species }\end{array}$ & IVI & Rank & $\begin{array}{l}\text { WEFT } \\
\text { species }\end{array}$ & Threats & Rank & $\begin{array}{l}\text { WEFT } \\
\text { species }\end{array}$ & $\begin{array}{l}\text { Sum } \\
\text { of ranks }\end{array}$ & Total \\
\hline $\begin{array}{l}\text { Dialium } \\
\text { guineense }\end{array}$ & 0.64 & 1 & $\begin{array}{l}\text { Dialium } \\
\text { guineense }\end{array}$ & Native & 1 & $\begin{array}{l}\text { Pterocarpus } \\
\text { santalinoides }\end{array}$ & 0.003 & 1 & $\begin{array}{l}\text { Psidium } \\
\text { guajava }\end{array}$ & EN & 1 & $\begin{array}{l}\text { Psidium } \\
\text { guajava }\end{array}$ & $2+2+6+1$ & 11 \\
\hline $\begin{array}{l}\text { Psidium } \\
\text { guajava }\end{array}$ & 0.49 & 2 & $\begin{array}{l}\text { Diospyros } \\
\text { mespiliformis }\end{array}$ & Native & 1 & $\begin{array}{l}\text { Ficus } \\
\text { capensis }\end{array}$ & 0.073 & 2 & $\begin{array}{l}\text { Ficus } \\
\text { capensis }\end{array}$ & VU & 2 & $\begin{array}{l}\text { Spondias } \\
\text { mombin }\end{array}$ & $3+2+4+3$ & 12 \\
\hline $\begin{array}{l}\text { Spondias } \\
\text { mombin }\end{array}$ & 0.163 & 3 & $\begin{array}{l}\text { Drypetes } \\
\text { floribunda }\end{array}$ & Native & 1 & $\begin{array}{l}\text { Pancovia } \\
\text { bijuga }\end{array}$ & 0.107 & 3 & $\begin{array}{l}\text { Mimusosps } \\
\text { andongensis }\end{array}$ & VU & 2 & $\begin{array}{l}\text { Ficus } \\
\text { capensis }\end{array}$ & $7+1+2+2$ & 12 \\
\hline $\begin{array}{l}\text { Diospyros } \\
\text { mespiliformis }\end{array}$ & 0.04 & 4 & $\begin{array}{l}\text { Pancovia } \\
\text { bijuga }\end{array}$ & Native & 1 & $\begin{array}{l}\text { Spondias } \\
\text { mombin }\end{array}$ & 0.178 & 4 & $\begin{array}{l}\text { Pterocarpus } \\
\text { santalinoides }\end{array}$ & VU & 2 & $\begin{array}{l}\text { Pterocarpus } \\
\text { santalinoides }\end{array}$ & $10+1+1+2$ & 14 \\
\hline $\begin{array}{l}\text { Drypetes } \\
\text { floribunda }\end{array}$ & 0.023 & 5 & $\begin{array}{l}\text { Lecaniodiscus } \\
\text { cupanioides }\end{array}$ & Native & 1 & $\begin{array}{l}\text { Drypetes } \\
\text { floribunda }\end{array}$ & 0.224 & 5 & $\begin{array}{l}\text { Lecaniodiscus } \\
\text { cupanioides }\end{array}$ & NT & 3 & $\begin{array}{l}\text { Pancovia } \\
\text { bijuga }\end{array}$ & $6+1+3+5$ & 15 \\
\hline $\begin{array}{l}\text { Pancovia } \\
\text { bijuga }\end{array}$ & 0.017 & 6 & $\begin{array}{l}\text { Ficus } \\
\text { capensis }\end{array}$ & Native & 1 & $\begin{array}{l}\text { Psidium } \\
\text { guajava }\end{array}$ & 0.236 & 6 & $\begin{array}{l}\text { Spondias } \\
\text { mombin }\end{array}$ & NT & 3 & $\begin{array}{l}\text { Dialium } \\
\text { guineense }\end{array}$ & $1+1+10+4$ & 16 \\
\hline $\begin{array}{l}\text { Ficus } \\
\text { capensis }\end{array}$ & 0.01 & 7 & $\begin{array}{l}\text { Mimusosps } \\
\text { andongensis }\end{array}$ & Native & 1 & $\begin{array}{l}\text { Mimusosps } \\
\text { andongensis }\end{array}$ & 0.284 & 7 & $\begin{array}{l}\text { Dialium } \\
\text { guineense }\end{array}$ & LC & 4 & $\begin{array}{l}\text { Drypetes } \\
\text { floribunda }\end{array}$ & $5+1+5+5$ & 16 \\
\hline $\begin{array}{l}\text { Lecaniodiscus } \\
\text { cupanioides }\end{array}$ & 0.01 & 8 & $\begin{array}{l}\text { Pterocarpus } \\
\text { santalinoides }\end{array}$ & Native & 1 & $\begin{array}{l}\text { Lecaniodiscus } \\
\text { cupanioides }\end{array}$ & 0.378 & 8 & $\begin{array}{l}\text { Diospyros } \\
\text { mespiliformis }\end{array}$ & LC & 4 & $\begin{array}{l}\text { Diospyros } \\
\text { mespiliformis }\end{array}$ & $4+1+9+4$ & 18 \\
\hline $\begin{array}{l}\text { Mimusosps } \\
\text { andongensis }\end{array}$ & 0.01 & 9 & $\begin{array}{l}\text { Psidium } \\
\text { guajava }\end{array}$ & Introduced & 2 & $\begin{array}{l}\text { Diospyros } \\
\text { mespiliformis }\end{array}$ & 0.794 & 9 & $\begin{array}{l}\text { Drypetes } \\
\text { floribunda }\end{array}$ & DD & 5 & $\begin{array}{l}\text { Mimusosps } \\
\text { andongensis }\end{array}$ & $9+1+7+2$ & 19 \\
\hline $\begin{array}{l}\text { Pterocarpus } \\
\text { santalinoides }\end{array}$ & 0.01 & 10 & $\begin{array}{l}\text { Spondias } \\
\text { mombin }\end{array}$ & Introduced & 2 & $\begin{array}{l}\text { Dialium } \\
\text { guineense }\end{array}$ & 1.424 & 10 & $\begin{array}{l}\text { Pancovia } \\
\text { bijuga }\end{array}$ & $\mathrm{DD}$ & 5 & $\begin{array}{l}\text { Lecaniodiscus } \\
\text { cupanioides }\end{array}$ & $8+1+8+3$ & 20 \\
\hline
\end{tabular}

Table IV.

Uses of the Wild Edible Fruit Trees (WEFT) species by the riparian populations of the Lama Forest Reserve.

\begin{tabular}{|l|l|l|l|}
\hline WEFT species & Organs & Medicinal uses & Food uses \\
\hline \multirow{2}{*}{ Dialium guineense } & Fruit & & Eaten raw \\
\hline & Leaves & To cure malaria & Eaten raw \\
\hline Bark & To recover the dissolute menses & \\
\hline Root & Against spot & \\
\hline Psidium guajava & Fruit & Against dysentery & \\
\hline Leaves & Bark & Against cough & \\
\hline Root & To correct bad breath \\
\hline Leaves & To accelerate the childbirth with herbivorous \\
\hline & Healing of circumcision wound \\
\hline & To improve oligospermy \\
\hline & To cure measlves \\
\hline
\end{tabular}




\section{Discussion}

\section{Diversity, ecology and structure of the WEFT species}

The study assessed the diversity of WEFT species within the Lama Forest Reserve. The inventory showed 10 WEFT species belonging to 10 Genera and 8 plant families in the Lama Forest Reserve. Actually, the equilibrium disruption of the Lama Forest Reserve due to the high degradation of its structure in certain locations (degraded dense forest and fallows), coming from human's activities, explained the low WEFT specific richness (10 species) in this forest (Djodjouwin and Sinsin, 2007). The high nutritional value, the easy access and the good organoleptic quality of WEFT species may also explain their overexploitation in the Lama Forest Reserve prior to the protection by law (Assogbadjo et al., 2008; Debella et al., 2011). Results of WEFT species inventory in other ecosystems in Benin revealed 52 species of WEFT belonging to 45 genera and 37 families in the Pendjari Biosphere and 115 species of WEFT species belonging to 92 genera and 48 families in Bassila Reserve (Vodouhê et al., 2009; Segnon and Achigan-Dako, 2014). This relatively low diversity of WEFT species in Lama Forest Reserve could be explained by both the area covered by the forest (less than Pendjari and Bassila reserve), and the deep clay soil in the Lama Forest Reserve ( $>2 \mathrm{~m}$ in depth), that causes flood during rainy seasons and cracks in dry seasons, which, according to Emrich et al. (1999), leads to a relatively poor flora in forests. The variation in density of WEFT species from one vegetation type to another may be explained by the difference in ecological patterns (slope, disturbance, moisture, soil characteristics) within each vegetation type. For instance, the plant density increases in an environment where the optimum conditions are met. The WEFT species such as: $D$. guineense, D. mespiliformis, and $M$. andogensis presented a high trees density $(120,83$ and 64 trees/ha respectively) in the typical dense forest because their ecological requirements were met in that vegetation type. These results are consistent with the findings of Assongba et al. (2014) who found that the density of $D$. guineense is high in the dense forest compared to the fallows and home gardens. Similar results were obtained by Lokonon (2008) while evaluating the structure of $D$. guineense and $D$. mespiliformis in the Lama Forest Reserve. In addition, the high density of the WEFT species observed in the typical dense forest may be explained by the non-degraded status of that vegetation type which is scarcely disturbed. Unlike that, the density is relatively low in the degraded dense forest, suggesting low rate of forest regeneration.

Similar to what Djodjouwin et al. (2011) found, $D$. guineense, $M$. andongensis, and $P$. bijuga presented a value of Green index greater than 1 in the young fallow. This suggests a large variation in densities among plots within this vegetation type. This could be imputable to the change in floristic composition and change in environmental conditions. The value of the Green index less than 1 in the typical dense forest, reflects a relatively homogeneous distribution of the WEFT species in that vegetation type. Similar spatial pattern was observed by Hounkpèvi (2010) in the Lama Forest Reserve, where a random distribution pattern of D. mespiliformis, M. andogensis and Lonchocarpus sericeus (Poir.) Kunth ex DC. was noticed while evaluating the ecological and structural characteristics of plant communities within the forest. From the conservation point of view, the predominance of young individuals, suggested that the species are not overexploited by the riparian populations and they are more preserved in this protected forests (Assongba et al., 2013).

Among the ten WEFT species, D. guineense and $D$. mespiliformis were the most abundant and found together in the same plot within the different vegetation types. This may be an indication that these two are co-occurring species. However, further investigations in other forests are needed to test for this hypothesis.

\section{Most used wild edible fruit tree species}

Ethnobotanical use values indicated that $D$. guineense, P. guajava and S. mombin were the most used WEFT species. This is consistent with the earlier investigations of Ambé (2000) in Seguela (Ivory Coast), whereby, D. guineense and S. mombin were the most frequently used among the 55 WEFT species classified. This could be imputable to their sweet taste and their availability. The diverse uses of the abovementioned species clearly explains their high use values as mentioned earlier by Oryema et al. (2010) and Belinda et al. (2013). Unfortunately, these species mostly used by the populations are collected from the major part of the reserve. Further inclusion in plantation programmes and in agroforestry systems could help to reduce human pressure on the Lama Forest Reserve. Besides, these species fulfill the three main reasons (contribution as food, medicinal uses and perceptions on availability) identified by Assogbadjo et al. (2012) which support peasant ambition to conserve or grow WEFT species in farmland.

In addition, inclusion of these species in the home gardens, the botanical gardens throughout the country could also contribute to their ex-situ conservation.

\section{Priority species deserving active conservation}

P. guajava, S. mombin, F. capensis, P. santalinoides, $P$. bijuga were defined as the top priority WEFT species for conservation using Compound Ranking System method. In fact, these species are highly used by the local populations and are lowly represented in the Lama Forest Reserve. That conditions confer to them the highest rank among the WEFT species recorded in this forest. This priority list provides a strong basis for sustainable management at affordable cost, as handling a huge number of species may not be cost efficient (Maxted et al., 2006). However, the presence of $P$. guajava and S. mombin, native from South America, in the list of the WFET species recorded in the Lama Forest Reserve may be explained by their introduction in the forest by the local populations who were living in the reserve before the protection status of the forest. This statement was verified by their high density found in the fallows that represent the living 


\section{References}

areas of the local populations. Hence, we recommend more protection efforts on the fallows and the degraded dense forests since these five WEFT species are predominantly present in the fallows and degraded dense forests. In addition these species could be selected by the forest managers in the plantation and the Lama's reserve enrichment program. The Lama Forest managers are encouraged to promote the introduction of these species in the local population agroforestry system to improve their availability near the population, hence less pressure on them in the protected areas. The ranking approach used in this study is in accordance with those used by Lawrence et al. (2005) in Cameroun, and Vodouhê et al. (2009) in Northern Benin. Compound Ranking System method is easy to verify, flexible and easy to apply for a large data (Idohou et al., 2013). N'Danikou et al. (2011) recommended the use of the Compound Ranking System method for studies of this type. Yet, the method used in the current study can be updated whenever new information is collected. As data were not always available for the IUCN status of species and conservation strategies, it is strongly recommended that priorities be reassessed and refined when more detailed information is available. Brehm et al.(2010) argue that prioritization of species should be a dynamic process and as noted by Heywood (1995), the success of any method of prioritization will depend, in large part, on the inclusion of results in conservation activities, and especially the support of the international community (hardware and financial) in the preservation of biodiversity.

\section{Conclusion}

The present study revealed that Lama Forest Reserve has ten (10) Wild Edible Fruit Trees (WEFT) species belonging to 10 genera and 8 botanical family. The ecological investigation, showed that dense forests (typical and degraded dense forests) sheltered the majority of the WEFT species. The prioritization conducted, revealed that the priority WEFT species were: Psidium guajava, Spondias mombin, Ficus capensis, Pterocarpus santalinoides, and Pancovia bijuga and these species are predominantly present in the fallows (young and old) and degraded dense forest. We recommend more protection efforts on the fallows and degraded dense forest to ensure the conservation of these species. In addition, these species should be included in the enrichment program of the reserve, as well in the areas surrounding the central core. But Dialium guineense, P. guajava, and S. mombin would be introduced in the plantation program and the population's farms in order to reduce the human pressure on the reserve. Permanent plots should also be established in this ecosystem in order to follow the dynamics of these species' populations. Together with the current study, additional studies will help to improve knowledge about these species' habitat according to the climatic zones of Benin.

\section{Acknowledgements}

Our acknowledgment goes to the University Cooperation for Development-Belgium (CUD) who financed this study and to the local population for their help during the data collection phase.
Akpona H. A., Djagoun C. A. M. S., Sinsin B., 2008. Ecology and ethnozoology of the three-cusped pangolin Manis tricuspis Raf. (Mammalia, Pholidota) in the Lama Forest Reserve, Benin. Mammalia, 72 (3): 198-202.

Ambé G. A., 2000. Wild edible fruits of Guinean savannah of Côte-d'Ivoire: Status of knowledge by the local population, the Malinké. Journal of Biotechnology, Agronomy, Society and Environment, 5 (1): 43-58.

Assogbadjo A. E., 2000. Biodiversity of forest food resources and their contribution to the local population's diet. Study case of Lama Forest. Agronomist Engineer's dissertation, University of Abomey-Calavi, Faculty of Agronomic Sciences, Benin, 129 p. Assogbadjo A. E., Amadji G., Glèlè Kakaï R. L., Mama A., Sinsin B., Van D. P., 2009. Ecological and ethnobotanical assessment of Jatropha curcas L. in Benin. International Journal of the Biological and Chemical Sciences, 3 (5): 1065-1077.

Assogbadjo A. E., Glèlè Kakaï R. L., Chadare F. J., Thomson L., Kyndt T., Sinsin B., Van Damme, P., 2008. Folk classification, perception, and preferences of baobab products in West Africa: Consequences for Species Conservation and Improvement. Economic Botany, 62 (1): 74-84.

Assogbadjo A. E., Glèlè Kakaï R. L., Vodouhê F. G., Djagoun C. A. M. S., Codjia J. T. C., Sinsin B., 2012. Biodiversity and socioeconomic factors supporting farmers' choice of wild edible trees in the agroforestry systems of Benin (West Africa). Forest Policy and Economics, 14 (1): 41-49.

Assongba Y. F., Deleke-Koko I., Yoka J., Djego J. G., Sinsin B., 2014. Caractérisation des habitats de Dialium guineense (Willd) en République du Bénin. Journal of Applied Biosciences, 83 : 7520-7534.

Assongba Y. F., Djègo G. J., Sinsin B., 2013. Distribution des habitats de Dialium guineense (Willd) (Fabaceae: Caesalpinioideae) dans les phytodistricts Est du Sud-Bénin. Bulletin scientifique de l'Institut national pour l'environnement et la conservation de la nature, $12: 1-16$.

Belinda M., Caballero J., Delgado S. A., Rafael L., 2013. Relationship between use value and ecological importance of floristic resources of seasonally dry tropical forest in the Balsas river basin, México. Economic Botany, 67 (1): 17-29.

Bonou W., Glèlè Kakaï R. L., Assogbadjo A. E., Fonton H. N., Sin$\sin$ B., 2009. Characterization of Afzelia africana habitat in the Lama Forest Reserve of Benin. Forest Ecology and Management, 258 (7): 1084-1092.

Brehm J. M., Maxted N., Loução M. A., Ford-Lloyd B. V., 2010. New approaches for establishing conservation priorities for socio-economically important plant species. Biodiversity and Conservation, 19 (9): 2715-2740.

Chadare F. J., Hounhouigan J. D., Lineman A. R., Nout M. J. R., Van B. M. A. J. S., 2008. Indigenous knowledge and processing of Adansonia digitata L. food products in Benin. Journal of Ecology of Food and Nutrition, 47 (4): 338-362.

Codjia J. T. C., Assogbadjo A. E., Ekue M. R., 2003. Diversity and valorization at local scale of forest food plant resources of Benin. Agriculture, 12 (5): 321-331.

Dagnelie P., 1998. Statistique théorique et appliquée volume 2, Tome 1. De Boeck et Larcier, Belgique, 508 p. 
Debella H. F., Jesse T. N., Zemede A., Nyangito M., 2011. Wild edible fruits of importance for human nutrition in semiarid parts of East Shewa zone, Ethiopia: Associated indigenous Knowledge and implications to food security. Pakistan Journal of Nutrition, 10 (1): 40-50.

Djego J. G., Sinsin B., 2007. Structure and floristic composition of Lama Forest. Which protected areas for western Africa? Conservation of biodiversity and development. Ed. IRD, France, 193 p.

Djodjouwin L., Glèlè Kakaï R. L., Sinsin B., 2011. Caractérisation structurale des formations naturelles enrichies en essences forestières locales : cas des vertisols de la Lama (Benin). International Journal of Biological and Chemical Sciences, 5 (4) : 1628-1638.

Djodjouwin L., Sinsin B., 2007. Expérience d'aménagement par enrichissement des formations forestières. In : Actes du $3^{\text {e }}$ séminaire international de RNSCC, Eds Mayaka T., de longh H. et Sinsin B., Cotonou, Bénin, 79-96.

Emrich A., Horst A., Küppers K., Sturm H. J., 1999. Integrated ecological assessment of Lama Forest Reserve in Benin. Report, ONAB-KFW-GTZ, Cotonou, Benin, 74 p.

Fandohan B., Assogbadjo A. E., Glèlè Kakaï R., Kyndt T., De Caluwé E., Codjia J. T. C., et al., 2010. Women's traditional knowledge, use value, and the contribution of tamarind (Tamarindus indica L.) to rural households' cash income in Benin. Economic Botany, 64 (3): 248-259.

FAO, 2010. Global Forest Resources Assessment, Main report, chapter 2. FAO Forestry paper $n^{\circ} 153$. Rome, 44 p. www.fao.org

FAO, 2012. State of the World's Forests, Main report, chapter 2. FAO Forestry paper $n^{\circ} 163$. Rome, 16 p. www.fao.org

Green R. H., 1966. Measurement of non-randomness in spatial distributions. Journal of Researches on Population Ecology, 8 (1): 1-7.

Hermans M., Akoègninou A., Van Der M. L. J. G., 2004. Medicinal plants used to treat malaria in Southern-Benin. Economic Botany, 58 (1): 239-252.

Heywood V. H., 1995. Global biodiversity assessment. $5^{\text {th }}$ ed. United National Environment Programme. Cambridge University Press, Cambridge, $127 \mathrm{p}$.

Hounkpèvi A., 2010. Ecological and structural characteristics of forest plant communities of Massi and Koto (Lama, south Benin). Master's thesis, University of Abomey-Calavi, Faculty of Agronomic Sciences, Benin, 80 p.

Idohou R., Assogbadjo A. E., Fandohan B., Gouwakinnou G. N., Glèlè Kakaî R. L., Sinsin B., Maxted N., 2013. National inventory and prioritization of crop wild relatives: case study for Benin. Genetic Resources and Crop Evolution, 60 (4): 1337-1352.

Ihaka R., Gentlman R., 1996. R, a language for data analysis and graphics. Journal of Computational and Graphical Statistics, 5 (3): 299-314. www.r.projet.org

IUCN, 2011. Red List of Threatened Species. $2^{\text {nd }}$ ed., 87p. www. iucnredlist.org

Johnson N. L., Kotz S., 1970. Distributions in statistics: continuous univariate distributions. John Wiley and Sons, New York, 201 p.

Kebu B., Fassil K., 2006. Ethnobotanical study of wild edible plants in Derashe and Kucha Districts, South Ethiopia. Journal of Ethnobiology and Ethnomedicine, 2 (53): 1-9.

Kusters K. R., Achdiawan B., Belcher R. M., 2006. Balancing development and conservation? An assessment of livelihood and environmental outcomes of Non-Timber Forest Product trade in Asia, Africa, and Latin America. Ecology and Society, $11(2): 1-22$.
Lawrence A., Phillips O. L., Ismodes A. R., Lopez M., Roses W., Farfan A. J., 2005. Local values for harvested forest plants in Madrede Dios, Peru: Towards a more contextualized interpretation of quantitative ethnobotanical data. Biodiversity Conservation, 14 (1): 45-79.

Lokonon B. E., 2008. Structure et ethnobotanique de Dialium guineense Willd., Diospyros mespiliformis Hochst. ex A. Rich et Mimusops andongensis Hiern en populations dans le Noyau Central de la Forêt Classée de la Lama (Sud-Bénin). Thèse d'ingénieur agronome, Université d’Abomey Calavi, Faculté des Sciences Agronomiques, Bénin, 183 p.

Mahapatra A. K., Albers H. J., Robinson E. J. Z., 2005. Impact of NFTP sales on rural households' cash income in India's dry deciduous forest. Environmental Management, 35 (3): 258-265.

Mahapatra A. K., Mishra S., Basak U. C., Panda P. C., 2012. Nutrient analysis of some selected wild edible fruits of deciduous forests of India: an explorative study towards non-conventional bio-nutrition. Journal of Food Science and Technology, 4 (1): 15-21.

Maxted N., Ford-Lloyd B. V., Jury S., Kell S. P., Scholten M. A., 2006. Towards a definition of a crop wild relatives. Biodiversity and Conservation, 15 (8): 2673-2685.

N’Danikou S., Achigan-Dako E., Wong J. L. G., 2011. Eliciting local values of wild edible plants in Southern-Benin to identify priority species for conservation. Economic Botany, 65 (4): 381-395.

Oryema C., Ziraba R. B., Nelson O., Alfonse O., 2010. Medicinal plants of Erute County, Lira district, Uganda with particular reference to their conservation. African Journal of Ecology, 48 (2): 285-298.

Phillips O., Gentry A., 1993. The useful plants of Tambopata Peru: statistical hypotheses tests with a new quantitative technique. Economic Botany, 47 (1): 15-32.

Racquel T. C. B., 2014. Ethnobotanical survey of edible wild fruits in Benguet, Cordillera administrative region, the Philippines. Asian Pacific Journal of Tropical Biomedicine, 4 (1): 525-538.

Rigg J., 2009. A particular place? Laos and its incorporation into development mainstream. Environment and Planning, 41 (3): 703-721.

Rondeux J., 1999. La mesure des arbres et des peuplements forestiers. $2^{\mathrm{e}}$ édition, Presses universitaires de Gembloux, $544 \mathrm{p}$.

Salako V. K., Glèlè Kakaï R. L., Assogbadjo A. E., Fandohan B., Houinato M., Palm R., 2013. Efficiency of inventory plot patterns in quantitative analysis of vegetation: a case study of tropical woodland and dense forest in Benin. Southern Forests, 75 (3): 137-143.

Segnon A. C., Achigan-Dako E. G., 2014. Comparative analysis of diversity and utilization of edible plants in arid and semi-arid areas in Benin. Journal of Ethnobiology and Ethnomedicine, 10: 1-20.

Takasaki Y., Barham B. L., Coomes O. T., 2004. Risk coping strategies in tropical forests: floods, illnesses, and resource extraction. Environment and Development Economics, 9 (2): 203-224.

Vodouhê G. F., Coulibaly O., Greene C., Sinsin B., 2009. Estimating local values of non-timber forest products to Pendjari biosphere reserve dwellers in Benin. Economic Botany, 63 (4): 397-412.

White F., 1983. The vegetation of Africa: A descriptive memoir to accompany the Unesco/AETFAT/UNSO vegetation map of Africa. UNESCO, Paris, 356 p. http://unesdoc.unesco.org/images/0005/000580/058054eo.pdf 